\title{
Pengaruh Penggunaan Rumput Kebar (Biophytum petsianum Clotzch) dalam Konsentrat Berdasarkan Kandungan Protein Kasar 19\% terhadap Penampilan Kelinci
}

\author{
Martha Kayadoe, O.R. Faidiban, Purwaningsih dan Dwi Nurhayati \\ Program Studi Peternakan, Fakultas Peternakan Perikanan dan Ilmu Kelautan \\ Universitas Negeri Papua. \\ Jl. Gunung Salju, Amban. Kode Pos. 98314. Papua Barat \\ Korespondensi: E-mail: kayadoem@yahoo.co.id
}

\begin{abstract}
ABSTRAK
Penelitian ini untuk mengetahui performans kelinci yang diberi konsentrat dengan beragam formula rumput kebar (0, 5, 10 dan 15\%) berdasarkan batasan kebutuhan protein kasar 19\%. Penelitian menggunakan Rancangan Acak Kelompok dan setiap perlakuan diulang 2 kali. Data dianalisis dengan sidik ragam dan dilanjutkan dengan uji BNT. Peningkatan jumlah rumput kebar dalam formulasi konsentrat tidak menunjukkan pengaruh terhadap konsumsi ransum dan efisiensi ransum, namun pada formula 10\% rumput kebar (perlakuan C) dan 15\% rumput kebar (perlakuan D) menunjukkan pengaruh yang nyata $(\mathrm{P}<0,05)$ terhadap pertambahan bobot badan kelinci dibanding dengan perlakuan tanpa diberi rumput kebar dalam formula konsentrat (perlakuan A) dan 5\% rumput kebar (perlakuan B). Tingkat konsumsi ransum yang lebih baik pada perlakuan C (10\%) dan D (15\%), sehingga penambahan rumput kebar tidak mempengaruhi palatabilitas.
\end{abstract}

Kata kunci : rumput kebar, kelinci, konsentrat, formulasi

\section{Effect of Kebar Grass (Biophytum petsianum Clotzch) in Consentrates Containing 19\% Crude Protein on Performances of Rabbit}

\begin{abstract}
The objective of this study was to investigate the performances of rabbit using several levels of Kebar grass in concentrate, i.e. 0, 5, 10 and 15\%, according to protein requirement 19\%. Research designed by using Randomized Design Group and each treatment was replicated two times. Data were analyzed using Analysis of Variance and Continued with LSD test. The addition of kebar grass concentrates had no effect in ration and feed efficiency, but significantly affect body weight gain in treatment of $10 \%$ and $15 \%$ compared to without addition (0\%) of kebar grass and $5 \%$. The addition of kebar grass did not affect palatability.
\end{abstract}

Key words : kebar grass, rabbit, concentrate, formulations 


\section{PENDAHULUAN}

Kelinci dikenal oleh masyarakat sebagai hewan peliharaan yang dimanfaatkan daging dan bulunya. Daging kelinci mengandung kolesterol lebih sedikit dibanding ternak lainnya dan dalam sistem pemeliharaan membutuhkan lahan yang tidak luas dan mudah penanganannya.

Faktor pakan sangat penting dan tergantung dalam ketersediaan dan kebutuhan kelinci itu sendiri. Meredith dalam Manshur (2009) melaporkan bahwa nutrisi yang dibutuhkan berkisar antara 1619\% protein kasar dan 20-25\% serat kasar. Ambang batas minimum protein kasar dan serat kasar ini diperlukan karena bila tidak diperhitungkan akan berpengaruh terhadap performansnya. Nutrisi yang diperlukan ini akan diperoleh terutama melalui pakan yang dikonsumsi. Ternak kelinci yang diperlihara masyarakat umumnya mengkonsumsi hijauan berupa rumput dan sayur-sayuran disertai konsentrat yang telah diformula sesuai kebutuhan kelinci.

Rumput kebar dijumpai di daerah Papua, khususnya di Distrik Kebar Kabupaten Manokwari. Bila dilihat dari sisi kandungan protein kasarnya tidak jauh bebeda dengan protein kasar di dalam rumput (berkisar 8\%). Wujud yang sering dijumpai di pasaran adalah dalam bentuk kering udara karena bertujuan supaya tidak rusak bila didistribusi ke tempat lain. Mengingat wujudnya dalam kering udara, maka bisa dimungkinkan untuk digunakan sebagai salah satu bahan pakan dalam membuat formula konsentrat.

Konsentrat terdiri dari beberapa bahan pakan dan disusun atau diformulasikan sesuai dengan kebutuhan nutrisi dari ternak kelinci. Jumlah rumput kebar yang diperlukan dalam pembuatan konsentrat perlu dipertimbangkan sehingga penambahannya diharapkan akan memberi efek yang positif dengan berpedoman pada standar kebutuhannya. Oleh karena itu, penelitian penambahan rumput kebar dalam formula konsentrat diurutkan dari 5\%, 10\%, dan $15 \%$ sehingga dapat dilihat sampai sejauh mana pengaruhnya terhadap performans kelinci (konsumsi ransum, pertambahan bobot badan dan efisiensi ransum). Penelitian ini sebagai penelitian awal untuk keberlanjutan penelitian berikutnya.

\section{MATERI DAN METODE}

Bahan yang digunakan dalam penelitian adalah konsentrat dalam bentuk pellet(terdiri dari rumput kebar, kedelai, jagung, pakan basal (daun ubi jalar), kelinci betina 8 ekor,air minum, dan alat yang digunakan berupa kandang individu, tempat pakan dan tempat minum, dan mesin pelet.

Penelitian menggunakan rancangan acak kelompok berdasarkan bobot badan (terkecil dan terbesar) yang terdiri dari 4 perlakuan yaitu perlakuan A tanpa rumput kebar (63,83\% jagung+36,17\% kedelai), perlakuan B (5\% rumput kebar+61,99\% jagung+33,01\% kedelai), perlakuan C (10\% rumput kebar $+60 \%$ jagung $+30 \%$ kedelai), perlakuan C (15\% rumput kebar $+57,87 \%$ jagung $+27,13 \%$ kedelai, dengan protein kasar 19\% dalam konsentrat. Masing-masing perlakuan terdiri dari 2 ulangan.

Pelaksanaan penelitian meliputi: tahap pembuatan konsentrat melalui proses penggilingan bahan bahan formula (rumput kebar, jagung dan kedelai), proses pembentukan pakan menjadi pelet menggunakan mesin pelet manual, dan pengeringan pelet dalam oven dengan suhu $60^{\circ} \mathrm{C}$ selama 48 jam. Selanjutnya tahap pemberian pakan yang dilakukan dalam 2 periode yaitu periode adaptasi selama 1 minggu dan periode pengumpulan data selama 2 minggu yang meliputi konsumsi ransum, pertambahan bobot badan, prosentasi serat kasar yang dikonsumsi dan nilai efisiensi ransum.

\section{HASIL DAN PEMBAHASAN}

\section{Konsumsi Ransum}

Konsumsi ransum yang diberikan terdiri dari rumput kebar, jagung dan kedelai 
Tabel 2. Konsumsi ransum pada kelinci yang diberi tambahan rumput kebar berdasarkan kandungan protein kasar ransum 19\%.

\begin{tabular}{cccc}
\hline Perlakuan & \multicolumn{3}{c}{ Konsumsi Ransum (g BK/ekor/minggu) } \\
\cline { 2 - 4 } & 1 & 2 & Rata-rata \\
\hline A & 194,3 & 280,0 & 237,15 \\
B & 176,0 & 185,6 & 180,8 \\
C & 280,0 & 280,0 & 280,0 \\
D & 280,0 & 280,0 & 280,0 \\
\hline
\end{tabular}

Tabel 3. Komposisi serat kasar pada masing-masing perlakuan

\begin{tabular}{cccc}
\hline Perlakuan & \multicolumn{3}{c}{ \% Serat Kasar dalam ransum terkonsumsi } \\
\cline { 2 - 4 } & Ulangan 1 & Ulangan 2 & Rata - rata \\
\hline A & 19,427 & 24,510 & 21,9685 \\
B & 24,9299 & 18,4466 & 21,6883 \\
C & 26,5037 & 26,5037 & 26,5037 \\
D & 27,6333 & 27,6333 & 27,6333 \\
\hline
\end{tabular}

Tabel 4. Pertambahan bobot badan kelinci yang diberi rumput kebar berdasarkan protein kasar $19 \%$ dalam ransum.

\begin{tabular}{cccc}
\hline Perlakuan & \multicolumn{3}{c}{ Pertambahan bobot badan g/ekor/minggu } \\
\cline { 2 - 4 } & Ulangan 1 & Ulangan 2 & Rata - rata \\
\hline A & 30 & 50 & 40 \\
B & 30 & 80 & 55 \\
C & 120 & 160 & 140 \\
D & 220 & 140 & 180 \\
\hline
\end{tabular}

sebagai ransum kelinci berdasarkan kandungan protein kasar 19\% disajikan pada Tabel 2.

Dari Tabel 2 terlihat bahwa penambahan rumput kebar dalam formula konsentrat pakan kelinci secara statistik tidak menunjukkan pengaruh yang nyata $(\mathrm{P}<0,05)$ terhadap konsumsi ransum. Hal ini diduga karena pakan bentuk pelet disukaikelinci dan rumput kebar termasuk di dalamnya, baik dalam jumlah 5\%, 10\% hingga $15 \%$. Namun secara tabulasi nilai konsumsi ransum tertinggi terlihat pada perlakuan C dan D yaitu sebesar 280 g/ekor/minggu. Sedangkan dalam bentuk konsentrat ternyata tidak menurunkan nilai palatabilitasnya. Manshur (2009) memberi rekomondasi untuk kelinci umur 2-4 bulan rata-rata diberi konsentrat $70 \mathrm{~g} /$ hari atau 490 g/minggu, namun dari penelitian ini terlihat rata-rata terkonsumsi 40 g/hari atau 280 g/minggu. Perbedaan ini kemungkinan disebabkan faktor kelinci.

\section{Komposisi Serat Kasar dalam Ransum Terkonsumsi}

Komposisi serat kasar dalam ransum yang terkonsumsi pada masing masing perlakuan disajikan pada Tabel 3.

Berdasarkan Tabel 3 di atas terlihat bahwa serat kasar yang dikonsumsi pada perlakuan B sama dengan perlakuan A, sedangkan perlakuan $\mathrm{C}$ dan $\mathrm{D}$ lebih tinggi dibanding pada perlakuan A (0\%) maupun B (5\%). Tinggi rendahnya kandungan serat kasar ini seiring dengan jumlah ransum yang dikonsumsi. Kandungan serat kasar dalam pakan kelinci dianjurkan berkisar 20 - 25\% (Manshur, 2009). 
Tabel 5. Efisiensi ransum kelinci yang diberi rumput kebar berdasarkan protein kasar 19\% dalam ransum.

\begin{tabular}{cccc}
\hline Perlakuan & \multicolumn{3}{c}{ Efisiensi Ransum } \\
\cline { 2 - 4 } & Ulangan 1 & Ulangan 2 & Rata - rata \\
\hline A & 0,15 & 0,18 & 0,165 \\
B & 0,16 & 0,46 & 0,31 \\
C & 0,64 & 0,57 & 0,605 \\
D & 0,50 & 0,79 & 0,645 \\
\hline
\end{tabular}

\section{Pertambahan Bobot Badan}

Pertambahan bobot badan kelinci yang diberi rumput kebar dalam ransum berdasarkan kandungan protein 19\% disajikan pada Tabel 4. Penambahan rumput kebar dalam formula konsentrat pakan kelinci secara statistik menunjukkan pengaruh yang nyata $(\mathrm{P}<0,05)$ terhadap pertambahan bobot badan. Pengaruh yang nyata terlihat antara perlakuan C (10\% rumput kebar) dan D (15\% rumput kebar) terhadap perlakuan A (tanpa penambahan rumput kebar) dan secara tabulasi nyata terlihat perlakuan $\mathrm{C}$ dan $\mathrm{D}$ memiliki nilai pertambahan bobot badan lebih tinggi bila dibanding dengan tanpa diberi rumput kebar (lebih dari 100g/ekor/minggu). Hal ini kemungkinan disebabkan oleh tingkat konsumsi pada perlakuan C dan D juga lebih baik. Selain itu juga faktor bentuk fisik bahan makanan akan mempengaruhi kecernaan yang secara langsung akan berpengaruh terhadap penyerapan zat-zat makanan, karena didukung juga dengan adanya penambahan nutrien dari konsentrat lebih terlihat di perlakuan C dan D. Tillman et al. (1991) menyatakan bahwa pembuatan pelet akan memperbanyak konsumsi ransum, dan jumlah ransum yang dikonsumsi berkaitan erat dengan bobot badan (Church, 1980) dalam Toha (1994).

\section{Efisiensi Ransum}

Efisiensi ransum pada kelinci yang diberi rumput kebar dalam konsentrat berdasarkan kandungan protein 19\% disajikan pada Tabel 5.
Dari Tabel 5 terlihat bahwa penambahan rumput kebar dalam formula konsentrat pakan kelinci secara statistik tidak menunjukkan pengaruh nyata $(\mathrm{P}<0,05)$ terhadap efisiensi ransum. Hal ini diduga karena laju pertambahan bobot badan hampir seiring dengan tingkat konsumsi ransum. Namun secara tabulasi ternyata perlakuan $\mathrm{C}$ dan $\mathrm{D}$ lebih efisien dalam pemanfaatan ransum untuk pertambahan bobot badan dibanding dengan perlakuan A (0\% rumput kebar) dan perlakuan B (5\% rumput kebar).

\section{KESIMPULAN DAN SARAN}

Pemberian rumput kebar sebagai salah satu bahan penyusun dalam fornulasi konsentrat kelinci menunjukkan nilai manfaat terhadap performans kelinci pada taraf $10 \%$ dan $15 \%$ dibanding dengan perlakuan yang konsentratnya tidak mengandung rumput kebar.

Perlu dilanjutkan pengamatan pada kelinci yang diberi konsentrat ini yang mengandung rumput kebar sebagai salah satu bahan formula terhadap reproduksinya.

\section{DAFTAR PUSTAKA}

Azlina, 2009. Pengaruh Pemberian Ekstrak Rumput Kebar (Biophytum petersianum Clotzch) Terhadap Fertilitas Tikus Jantan (Rattus novergigus www.docstoc.organisasi-transformasikelahiran. Diunduh tanggal 3 Maret 2011.

Toha, Md., Farizaldi., D. Darmawi., I. Dewata., H. Ediyanto. Nelson 1994. Pengaruh Pemberian Biji Karet (Hevea brasilliensis) 
Dalam Ransum Terhadap Pertumbuhan Domba. Majalah Ilmiah. No.41.

Hustamin, R. 2006. Panduan Memelihara kelinci Hias. Agro Media Pustaka. Jakarta.

Kartadisastra, H.R., 1994. Kelinci Unggul. Kanisius. Yogyakarta.

Manshur, F. 2009. Kelinci Pemeliharaan Secara Alamiah, Tepat dan Terpadu. Nuansa. Bandung.

Siappa, H. 2001. Efek Infusa Rumput Kebar (Biophytum dendroides) Pada Induk Mencit
Betina (Mus musculus) Terhadap Fetus yang Dikandung. Sinta.ukdw.ac.id. diunduh tanggal 3 Maret 2011.

Subroto, S. 2006. Beternak Kelinci. Aneka Ilmu. Demak.

Tillman, A.D., H. Hartadi., S. Reksohadiprodjo, S. Prawirokusumo dan S. Labdosoekojo. 1991. Ilmu Makanan Ternak Dasar. Cetakan kelima. Gadjah Mada University Press. Fakultas Peternakan Universitas Gadjah Mada. Yogyakarta. 